ICTD Working Paper 134

\section{Tax Treaties and Enterprise Outcomes: Evidence Across Developing African Countries}

Uchenna Efobi and Oluwabunmi O. Adejumo

December 2021 
Tax Treaties and Enterprise Outcomes: Evidence Across Developing African Countries Uchenna Efobi and Oluwabunmi O. Adejumo

ICTD Working Paper 134

First published by the Institute of Development Studies in December 2021

(C) Institute of Development Studies 2021

ISBN: [978-1-78118-898-9]

DOI: $10.19088 /$ ICTD.2021.024

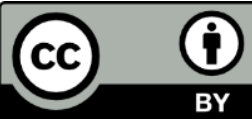

This is an Open Access paper distributed under the terms of the Creative Commons Attribution 4.0 International license (CC BY), which permits unrestricted use, distribution, and reproduction in any medium, provided the original authors and source are credited and any modifications or adaptations are indicated. http://creativecommons.org/licenses/by/4.0/legalcode

\section{Available from:}

The International Centre for Tax and Development at the Institute of Development Studies, Brighton BN1 9RE, UK

Tel: +44(0) 1273606261

Email: info@ictd.ac

Web: www.ictd.ac/publication

IDS is a charitable company limited by guarantee and registered in England

Charity Registration Number 306371

Charitable Company Number 877338 


\title{
Tax Treaties and Enterprise Outcomes: Evidence Across Developing African Countries
}

\author{
Uchenna Efobi and Oluwabunmi O. Adejumo
}

\section{Summary}

Studies have noted the possibility of tax treaties constraining the tax policy autonomy of developing countries, while their impact on enterprise development within host economies remains an empirical issue. This study examines the effects and heterogeneous differences in estimated effects of tax treaties on small businesses in developing countries that agree to these agreements. The study uses the ICTD tax treaties dataset and the World Bank Enterprise Survey data to set up a quasi-experiment framework for selected African Countries. The framework compares countries' outcomes for small businesses that ratify and enforce a tax treaty and those without a ratified tax treaty for the years pre-2005-2010 and post-2011-2019). We find that tax treaties signed and enforced by developing countries in Africa have a consistent, negative relationship with small business outcomes. These results are driven by the enterprise's size and internationalisation status but not by the subsidiary status of the sampled small businesses. The findings have implications for policy targeted towards industrial development alongside tax treaty negotiations.

Keywords: developing countries, high growth entrepreneurship, tax treaties

Uchenna Efobi is a research fellow at the Centre for the Study of the Economies of Africa (CSEA), Nigeria. Email: uefobi@cseaafrica.org

Oluwabunmi Oluwabunmi $\mathbf{O}$. Adejumo is a research fellow at the Centre for Economic Policy and Development Research (CEPDeR), Covenant University and a faculty of the Institute for Entrepreneurship and Development Studies, Obafemi Awolowo University, Nigeria. 


\section{Contents}

Summary 3

Acknowledgements $\quad 6$

$\begin{array}{ll}\text { Acronyms } & 7\end{array}$

$\begin{array}{lr}\text { Introduction } & 8\end{array}$

$1 \quad$ Literature review and analytical framework 9

$\begin{array}{lll}1.1 & \text { Literature review } & 9\end{array}$

$\begin{array}{lll}1.2 & \text { Analytical framework } & 10\end{array}$

$2 \quad$ Data and identification strategy 11

2.1.1 Data 11

2.1.2 Measuring enterprise outcomes $\quad 12$

2.1.3 Tax treaty agreement $\quad 12$

$\begin{array}{ll}2.2 & \text { Identification strategy and assumption } \\ \end{array}$

$3 \quad$ Analysis and results $\quad 15$

$\begin{array}{lll}3.1 & \text { Tax treaties in Africa } & 15\end{array}$

3.2 Tax treaties and small business outcomes 17

3.2.1 The effect of tax treaties on small business outcome 17

3.2.2 Correlation between tax treaty components and small business outcomes 18

$\begin{array}{lll}3.3 & \text { Additional robustness } & 20\end{array}$

3.4 Heterogeneous effects 22

4 Conclusion $\quad 23$

$\begin{array}{lr}\text { References } & 24\end{array}$

$\begin{array}{lr}\text { Appendices } & 27\end{array}$

$\begin{array}{lr}\text { Appendix } 1 & 27\end{array}$

\section{Figures}

Figure 1.2.1 Average outcome variables of enterprise by country group 15

Figure 3.1 Number of treaties by African countries 16

Figure 3.2 Number of times these features appear in tax treaties in Africa 17

Figure 3.3.1 Propensity scores before and after the matching 22

Figure A1.1 How treaties affect domestic enterprise 31

Tables

Table 3.2.1.1 Impact of a treaty on small business outcomes 18

Table 3.2.2.1 Correlational analysis - components of tax treaties and small business outcomes 19

Table 3.3.1 Impact of a treaty on small business outcomes (considering clustering at industry- and country-level) 20

Table 3.3.2 Impact of a treaty on small business outcomes (excluding firms from Malawi and Mali) 21

Table 3.3.3 Impact of a treaty on small business outcomes (using matched data) 22

Table A1.1 Sample countries by survey years $\quad 27$

Table A1.2 Test of difference in firms' characteristics at baseline 27

Table A1.3 Fixed effect regression - tax treaty and foreign investment 28 
Table A1.4 Heterogeneity by size of domestic firms 


\section{Acknowledgements}

The authors are grateful to Martin Hearson for his generosity in guiding us through the ICTD data and suggestions that improved the final version of this paper. We are also grateful to Jawad Ali Shah of the University of Kentucky, the editorial team at ICTD/IDS, and three anonymous reviewers for their valuable comments and suggestions. We also gratefully acknowledge the financial support from ICTD. We take responsibility for all errors. 


\section{Acronyms}

$\begin{array}{ll}\text { BTT } & \text { bilateral tax treaties } \\ \text { DD } & \text { difference-in-difference } \\ \text { DTT } & \text { double taxation treaty } \\ \text { ES } & \text { enterprise survey } \\ \text { FDI } & \text { Foreign direct investment } \\ \text { MNE } & \text { multinational enterprises } \\ \text { OECD } & \text { Organisation for Economic Co-operation and Development } \\ \text { PE } & \text { permanent establishment } \\ \text { R\&D } & \text { research and development } \\ \text { SSA } & \text { sub-Saharan Africa } \\ \text { UEA } & \text { United Arab Emirates } \\ \text { UN } & \text { United Nations } \\ \text { UNCTAD } & \text { United Nations Conference on Trade and Development }\end{array}$




\section{Introduction}

Spill-over effects on enterprise development in host countries from foreign investments (i.e. foreign direct investment [FDI]) can be positive or negative. On the one hand, some studies argue that FDI presence could increase competition in the local input and output market (Agbloyor, Abor, Adjasi and Yawson 2014) and crowd-out local enterprises that cannot compete with foreign firms. On the other hand, Reyes (2018) highlights that FDI could positively impact local enterprises through two main channels: the first is the contractual link through the demand for input from local suppliers, which results in the growth of indigenous businesses. The second is through improving the stock of human capital by hiring and training the indigenous workforce that later transmits such skills to local enterprises.

Despite the controversies over the impact of FDI on enterprise development in host countries, policymakers in developing countries are receptive to strategies that attract and support FDI for broad economic and industrial development ${ }^{1}$. Such strategies include signing tax treaties aimed at restricting if, how and how much multinationals are taxed to eliminate barriers to the inflow of foreign capital to host countries (see Hearson 2016). However, there are arguments showing that tax treaties constrain the tax policy autonomy of developing countries and, most important to this study, how they impact enterprise development, which still remains an empirical question.

This research sets out to answer three main research questions: (a) what is the effect of ratified tax treaties on small business outcomes? (b) what is the correlation between selected components of tax treaties and small business outcomes?, and (c) are there heterogeneous differences in the estimated effects by the size, the internationalisation status and the subsidiary status of small businesses in the host countries? We rely on the updated ICTD dataset on tax treaties and the World Bank Enterprise Survey data to set up a quasiexperiment framework. The framework compares the outcomes of small businesses in African countries that ratify and enforce a tax treaty and those in countries without a ratified tax treaty and for the years pre-2005-2010 and post-2011-2019 of such ratification. We control for the year, and industry fixed effect to adjust for unobservable differences at the time and industry levels. We cluster standard errors at the country level to improve our identification.

We find the following from our analysis: firstly, we show that the overall ratification of the tax treaty adversely affects small business outcomes. Specifically, small businesses in treaty countries record a significant decline of around 68 per cent in total revenues, a significant decline of 14.6 per cent in the likelihood of introducing a new product and a significant decline of 48 per cent in the size of employees. The estimates for total revenues and the number of employees are the magnitudes of decline from the mean of the enterprises in countries without tax treaty enforcement. These results are not sensitive to the inclusion (or otherwise) of control variables, and the results are robust to the clustering of standard errors at the industry-country level and the use of a matched sample for the difference-in-difference analysis.

Secondly, there is a 29 per cent significant correlational decline in staff size resulting from tax treaty components that align with the OECD model in delivering exceptions to permanent establishments. Furthermore, we find a 15 per cent decline in innovation from the inclusion of the provision for source capital gains on 'land rich' companies according to the

\footnotetext{
${ }^{1}$ For instance, there is consensus that FDI inflow is positively related to increasing technology and knowledge transfer, economic diversification and value addition, capital inflow, job creation and an increase in the productivity of domestic enterprises (Gui-Diby and Renard 2015; Thompson and Zang 2018).
} 
OECD and UN model. Regarding the provisions for withholding tax rate on interest and royalties, we find that a 1 per cent increase in the withholding tax rate respectively results in a 12.9 per cent increase in revenues and a 4 per cent increase in innovation. We interpret these results as the correlational effect of the different provisions of tax treaties on small business outcomes in developing countries.

Thirdly, we record some evidence of heterogeneity by the size of the enterprise, internationalisation exposure and not by the subsidiary status of the sampled firms, highlighting that small enterprises are worse off with tax treaties. In other words, the negative effect of tax treaties on the total revenue and employee size of the enterprise that we earlier recorded is mostly seen in small enterprises (i.e. those with more than ten and less than 50 workers). Furthermore, regarding the extent of innovation, we find that tax treaties significantly and negatively affect medium-sized enterprises. In addition, we see a significant negative effect of tax treaties on the total revenue and innovation for firms with no internationalisation exposure, unlike firms with some level of internationalisation.

Our findings contribute to the broad literature on tax treaty negotiations and their impact in developing countries. Hearson (2018) notes that factors that influence the likelihood of tax treaty negotiations and agreement in developing countries is informed by the size of the government's revenue base and the countries' reliance on corporate tax. Likewise, other studies examining tax treaty impacts have considered changes in foreign investment, such as Beer and Loeprick (2021), showing from a sample of 41 African economies from 1985-2015 that tax treaties do not increase foreign investment inflow. Similar findings were recorded in Egger, Larch, Pfaffermayr and Winner (2006), who link tax treaties to negative outward FDI stocks. On the other hand, Castillo-Murciego and LopezLaborda (2019) find a positive FDI effect from agreed rules in the Double Taxation Treaties by Spain and investors' residence country. Yet, other studies have considered the government revenue effect from tax treaties, including Beer and Loeprick (2021), who find an adverse effect on government revenues of SSA countries from bilateral tax treaties. Similarly, Janský and Šedivý (2019) also find revenue losses from tax treaties in developing countries. However, it is not clear from these studies how bilateral tax treaties signed by African countries affect domestic enterprises.

The heterogeneous effects explored in this study have important policy implications for advocacy intended to measure the effectiveness of tax treaties on specific and different small businesses in developing African countries. As we have shown, these effects vary by the size of the business and their level of international exposure. Finally, the findings of this study also have a practical application by highlighting that multinational companies attracted to developing countries from tax treaty agreements could have important implications for

domestic enterprise development in the treaty-partner African country. Therefore, our findings present important perspectives regarding the small business implication from bilateral fiscal agreements by African countries, which may be relevant information for consideration in future tax treaty negotiations by country in this region.

\section{Literature review and analytical framework}

\subsection{Literature review}

An important element in tax treaty negotiations is the mitigation of double taxation, especially as it applies to multinational enterprises with operations in multiple countries (Neumayer 2007). Blonigen, Oldenski and Sly (2014) note that the intention of bilateral tax treaties (BTTs) is to advance foreign direct investment through double-taxation relief. In 
addition to tax relief, Egger and Merlo (2011) added that treaties specify tax parameters that may be of interest between two countries (such as withholding tax, capital gains tax) and establish an agreement about information exchange to reduce tax avoidance. The view that tax treaties benefit developing countries by stimulating investment inflow is pervasive (Hearson 2018), but with varying conclusions. For example, Beer and Loeprick (2021) note that tax treaties (with investment hubs) are not associated with additional investment flow, which is similar to the conclusions in Egger et al. (2006). The authors find a negative relationship between treaties and the stock of outward FDI flows based on OECD data between 1985 and 2000. In essence, despite treaties being beneficial theoretically, their benefits (especially relating to stimulating investment) may be minimal (Davies 2004). On the other hand, Egger and Merlo (2011) find that a double taxation treaty induces a positive effect on multinational firm activities, relying on a two-part quasi maximum-likelihood model and panel data on the foreign businesses of German multinational enterprises (MNEs) between 1996-2005. Likewise, Barthel, Busse, Krever and Neumayer (2010), using an unpublished data set, find that double-taxation treaties (DTTs) cause a higher significant inflow of FDI stocks while acknowledging that a wide range of potential endogenous factors (including macro-political and economic changes, and change in economic policies) may explain both the rise in the number of treaties and the volume of FDI. Petkova, Stasio and Zagler (2020) further find that 'relevant' double tax treaties will increase FDI by about 18 per cent. A similar result is seen by Bloningen et al. (2014) and Castillo-Murciego and LópezLaborda (2019) studies with the conclusion of a positive effect of BTTs on FDI flow.

Yet, other studies have probed the efficacy of bilateral tax treaties on domestic revenue generation. Beer and Loeprick (2021) highlight that, by restricting taxing rights and through the abuse of treaty networks using shell companies, tax treaties can contribute to the loss of a country's tax base and facilitate tax avoidance. Similarly, Janský and Šedivý (2019) also find revenue losses from tax treaties in developing countries. Hence, as relevant and laudable as tax treaties may seem, there may be attendant costs on government revenues and investments, which can translate to adverse outcomes for domestic enterprises.

In realising the benefits from tax treaties, Quak and Timmis (2018) argue that there is a significant asymmetry in tax negotiations between high-income and low-income countries. Hearson (2018) highlights this issue, noting that the presence of power asymmetries between tax treaty signatories could shift taxing rights away from developing countries, which could adversely affect domestic revenue. Noting the non-asymmetrical nature of some tax treaties, some African countries such as South Africa, Zambia, and Rwanda are beginning to reconsider or revise (as in the case of Uganda) their agreements. Moreover, some developed economies, such as the Netherlands and Ireland, offered to renegotiate the conditions of their treaties (Hearson 2015). Our study extends this broad debate on tax treaty agreements and their impacts by focusing on domestic enterprises' effects in developing African countries.

\subsection{Analytical Framework}

We conceptualise the link between tax treaties and small business outcomes as arising in two stages. In the first stage, tax treaties imply a set of agreements between countries that specify tax parameters of interest at the bilateral level (such as withholding tax, capital gains tax) and establish an agreement about information exchange to reduce tax avoidance (Egger and Merlo 2011), which matters for: (a) domestic revenue generation; and (b) investment inflow. In the next stage, each of these outcomes from the tax treaties has implications for the primitives in a model of industrial development policies, namely (among others) the physical infrastructural conditions and spill-overs or other linkages that emanate from changes in domestic revenue and foreign investment flow (see Newman, Page, Rand, Shimeles, Soderbom and Tarp 2016). For instance, assuming tax treaties improve foreign investment inflow, some authors note a positive effect on industrial development (the value- 
added market outcome and employment growth) through: (a) competition and linkage effects (Gui-Diby and Renard 2015); (b) contractual linkage and improved stock of human capital by hiring and training the indigenous workforce that later transmits such skills to local enterprises (Reyes 2018); and (c) technology diffusions, innovation, technology transfer, and other joint venture agreements (Gorg and Strobl 2005; Falk 2015), among others. On the other hand, it is also possible that there are adverse small business outcomes from increasing foreign investment inflow as a result of tax treaties. These include that through competition, foreign investments could hurt small businesses (Nam and Young 2004). Furthermore, inefficiencies in small-business level of production from losses in market share and spreading fixed costs over smaller output as a result of rising competition could be an adverse outcome from rising foreign investment flow due to tax treaties (Lipsey 2004). Moreover, there could be a reduction in research and development (R\&D) efforts due to shrinking profit from aggressive competition from foreign investors.

Although there is no overwhelming evidence, some other authors find no significant impact of foreign investment on small business growth. For instance, Kaya (2010) finds no significant impact of FDI inflows on industrialisation for developing countries. Elu and Price (2010) observe no significant impact on total factor productivity for Chinese FDI in five SubSaharan African countries from 1992 to 2004.

In summary, tax treaties may lead to an exogenous shock (probably positive, but some studies find negative) on the flow of foreign capital. Any such shock would be expected to have an impact on small, domestically-owned businesses. It is this indirect impact of tax treaties that we seek to study.

\section{Data and identification strategy}

\subsubsection{Data}

This study relies on the World Bank's Enterprise Survey and the ICTD data on tax treaties worldwide to analyse the link between tax treaties and high-growth outcomes of firms. The Enterprise Survey (ES) is comprehensive and uses a standard questionnaire and uniform sampling method to produce cross-country comparable data on manufacturing and service firms. The survey generation strategy includes stratified samples on the sector, firm size (in terms of employees) and geographical location. The ES sample does not include firms with 100 per cent state ownership, and the example generated for each country is representative of the non-agricultural formal private economy. The ES data provides general information about the firm, sales and export, capacity utilisation, infrastructural service in the firm's community, employment level and growth rate, innovation, and other firm characteristics. The firm-level information offered in the ES will enable the inclusion of more control variables in our regression analysis.

To correctly set up the identification strategy, we have restricted our sample to only African countries with two or more data periods for the years 2005-2019. The ES allows for such a setup considering it includes a sufficient longitudinal component to achieve this study's objective. Following the approach of Ayyagari, Juarros, Peria and Singh (2016), we further excluded those firms with fewer than five permanent employees. In essence, the sampling for this study focuses on firms with more than ten and less than 250 employees. The final dataset is a repeated cross-section that includes information about these small businesses from nine African countries. 
The ICTD data, on the other hand, offer a rich set of information about tax treaties across countries, including over 23000 bilateral and multilateral agreements and amending instruments since 1970 by low and lower-middle-income countries in the sub-Sahara African and Asian region. We rely on the ratification date (i.e. when the treaty became in force or actual ratification), for which the ICTD dataset draws on the International Bureau on Fiscal Documentation, to identify countries in the treatment group ${ }^{2}$. This data is the only source for comprehensive information about global tax treaties (including the treaty's ratification date), in general, and those about African countries, specifically. The ICTD datasets were matched with the World Bank's Enterprise Survey to aid the data analysis of this study.

\subsubsection{Measuring Enterprise Outcomes}

The features of a high growth enterprise include outcomes such as sales and revenue growth, innovation, and job creation (Hsieh and Klenow 2014; Haltiwanger, Jarmin and Miranda 2016). Some studies argue that identifying high growth outcomes should entirely focus on specific firms' job creation potential since the concept implies that the firm plays a disproportionately large role in creating jobs (Haltiwanger et al. 2016; Hsieh and Klenow 2014). This study aligns with the conceptualisation of high-growth entrepreneurship measures by McKenzie (2017). We define this concept in this study to include total revenue, innovation and employment outcomes to capture the realities facing the industrial ecosystem in the African region, which could impact overall industrial development, economic growth and inclusiveness (Reyes 2017). For instance, survey data indicate that about 99.6 per cent of firms have fewer than ten workers, compared to the United States, where comparable manufacturing firms have 45 workers (Hsieh and Klenow 2014; McKenzie 2017). Likewise, innovation and research and development spending within the region are still incredibly low, accounting for about 1.1 per cent of global investments in R\&D in 2016. Therefore, measuring high growth entrepreneurship based on these three dimensions is relevant to our understanding of how tax treaties could matter in improving firm outcomes.

We measure the enterprise's total revenue from the response to the current sales as in the survey year, which we convert to the prevailing US $\$$ rate as in the survey year. This is the first outcome variable for this study. The second outcome variable - innovation - is measured at the firm level by relying on the answers to the survey question: during the last three years, did your establishment introduce any new or significantly improved products (goods or services)? If the response to this question is affirmative, we code it as ' 1 ' and otherwise, ' 0 '. This question about innovation is consistent across years and countries in the ES. The third outcome variable is the total employment of the enterprise, measured by relying on the responses to the Enterprise Survey question regarding the total full-time permanent workforce in their establishment.

\subsubsection{Tax treaty agreement}

The agreement facilitating capital flow - that is, tax treaties - is identified across sample African countries by relying on the ICTD dataset. We determine from this dataset the African countries and the year in which the treaty was ratified, as well as whether the tax treaty is with a top FDI flow country of origin, which is confirmed by the UNCTAD Statistics and other public databases. That is, a country is considered a top FDI flow country of origin if it is listed among the top ten FDI origin of the sampled African countries in the period of signing the treaty.

\footnotetext{
${ }^{2}$ Although the recent version of this data (which was not available at the time of this research) contains the exact date when the treaty became in force. We do not expect a significant deviation in our result when considering the exact date of the treaty becoming in force.
} 
In the Enterprise Survey sample, we identify four countries (Kenya, Lesotho, Malawi and Mali) that have a survey both before and after the tax treaty was ratified, dubbed the 'treatment group.' We identify additional five countries (Mauritania, Namibia, Sierra Leone, Swaziland and Uganda) that had no new treaties with a top ten FDI origin country coming into force during the sample period. We consider samples from these five countries as those in the 'comparison'. It is important at this point to note a specific limitation with our identification, which is that, due to data limitations, we are not able to have a comparison group that does not have any form of treaties prior to this study's sample period.

Tax treaty agreement is a dummy variable that takes the value 1 for countries after the year the tax treaty was ratified with a top capital and investment flowing country of origin. In the years before the ratification of the tax treaties in the countries in the treatment group and the comparison group of countries with no tax treaties and implementation in the sampled period, we coded the dummy variable as 0 . We identified the treatment group as such with a treaty with high investment flowing countries and those with a significant investment or capital stock in the sample countries. We identified treaty partner countries from the ICTD dataset and cross-reference them with the information on investment flow from the UNCTAD Statistics (and other public databases) to determine if the treaty is with a top ten investment flowing country of origin. For example, the main investor in Kenya and Lesotho with a tax treaty in force during the sample period is South Africa, while Mali was included in this group considering its increased economic collaboration with Morocco (The Economist 2014). Although Norway is not a top FDI investment flow to Malawi, it has committed significant investment in three priority sectors, including clean energy, financial institutions, and food and agribusiness, since 2017 (see Royal Norwegian Embassy 2019). In the robustness check, we examine whether the inclusion of samples from Mali and Malawi has an effect on the main results (see the section on robustness check).

The main variable of interest is the interaction of the binary variable that identifies the treatment sample with the binary indicator for the post- treaty ratification years. The tax treaty ratifications that we consider for this study are those that occurred in the period 2011-2014, which we classified as the tax ratification period. Therefore, we consider a pre-ratification period as the years 2005-2010 and the post-ratification period as the survey years during and after the ratification period (2011-2019), as we only consider data from the period 20052019 (see Table A1.1 for the distribution of survey data across countries).

\subsection{Identification strategy and assumption}

This study relies on a difference-in-difference setup to achieve its objective. It relies on the ratification of tax treaties between the sampled countries and the top investment and capital flow country of origin. This action acts as an exogenous shock to the supply of capital and investment to African countries. Building on the inconclusive literature on the relationship between tax treaties and foreign investment flow (Davies 2004; Egger et al. 2006; Barthel et al. 2010; Egger and Merlo 2011; Bloningen et al. 2014; Castillo-Murciego and López-Laborda 2019; Petkova et al. 2020), we begin by testing this relationship to identify if a tax treaty exerts a positive shock on foreign investment flow. The correlational evidence in Table A1.3 ${ }^{3}$ shows an improvement in FDI flow after tax treaty ratification.

Building on this evidence, we estimate the following model, where the outcomes of firm ' $i$ ' in country ' $j$ ' in sector/industry ' $k$ ' at time ' $t$ ' is a variant of the following:

\footnotetext{
${ }^{3}$ Table A1.3 presents correlational evidence of the association between the variable of interest (Post $\times$ Treaty) and the indicators of foreign capital flow - including, the ratio of foreign investment to GDP, log of the stock of portfolio investment and the ratio of the stock of foreign investment to gross fixed capital formation. The parsimonious regression includes a country and year fixed effects, and controls for the indicators of economic growth (the logarithm value of gross domestic product per capita), and general market price fluctuations (inflation rate).
} 


$$
\text { High growth }_{i, j, k, t}=\sigma \text { Post }_{t}+\alpha \text { Post } \times \text { Treaty }_{j, t}+\beta X_{i, j, k, t}+\gamma Z_{j, k, t}+\varepsilon_{i, j, k, t}
$$

Where high growth connotes the indicators of small business outcomes, while Post is a dummy 1 for the period after the ratification of the tax treaty agreement, mostly survey years from 2011 onward. The primary variable of interest is the interaction between the posttreaty dummy and the dummy if the country has a tax treaty. $X$ is a matrix of firm-level characteristics as presented in Table A1.2, while $Z$ is a matrix of country-level variables that can affect small business growth, such as inflation and GDP growth. The usual error term is denoted as $\varepsilon_{i, j, k, t}$. We control for the year- and industry-fixed effects and cluster the standard errors at the country level in the estimations.

The difference-in-difference (DD) estimation is used to estimate the effect of the tax treaty by comparing the changes in small business outcomes over time between a population of small businesses in countries that have ratified a treaty and a population of small businesses in countries that do not have or have not ratified such treaty. Our identification is closer to Ayyagari et al. (2016). The authors consider the employment growth of firms in countries that introduce credit bureau relative to firms in countries that do not enter such a reform. As it is in the authors' study, we also use a (fiscal) reform that is identifiable and comparable across the selected African countries. Therefore, the primary variable of interest Post $\times$ Treaty denotes the interaction of dummy for enterprises in the group of countries that entered into a tax treaty and ratified it with a dummy that identifies the years after the reform. Thus, this framework compares outcomes of enterprises in countries with a tax treaty that is ratified and countries without such tax treaties, and periods pre- and post-treaty ratification. Therefore, we are better able to examine the effect on high growth outcomes of enterprises by considering a countrywide shock to the supply of foreign capital. The tax treaty variable is lagged in the equation to allow the realisation of the effect over time.

This study's approach takes advantage of cross-country variation in tax treaty agreement and ratification by countries due to some proponent countries having such status while others do not have it. As a result, the difference-in-difference framework is in play while controlling for the fixed effects (to adjust some unobserved variations by the industry of the enterprise) and year fixed effects that adjust for macro variations across periods. Finally, we include the following firm-level characteristics: A dummy ' 1 ' if the firm engages in formal training of employees. The legal status of the firm - a binary indicator if the enterprise is a sole proprietor or a limited liability company; ownership status - if the firm has zero per cent ownership by the government; a binary indicator if the owner of the firm or top manager is a woman; the number of years of experience of the top manager in the current industry; and age of the enterprise - number of years firm has been in operation since its registration. Other indicators include a binary indicator if the registration status of the firm is formal, and if the enterprise engage in export. Technology utilisation of the firm is a binary indicator if the enterprise has a website.

We also include other variables reflecting the enterprise' external environment (if the firm faces any obstacle in accessing credit, business registration, or corruption), access to a line of credit (if the firm has any access to credit), access to overdraft (if the firm has any access to an overdraft), and asset valuation ('log' value of total land and machinery owned by the firm in US\$). Finally, the country-level control variables in the analysis are the per capita GDP and inflation rate. Standard errors are clustered at the country level throughout. We subsequently discuss other additional robustness checks.

Our identification relies on the assumption that, in the absence of the tax treaty agreement, the difference between the outcomes of enterprises in the non-tax treaty and tax treaty countries is equal to zero or constant over time. To test this assumption, we use the enterprise survey to analyse the difference in the outcome variables in years leading up to 
the tax treaty agreement periods. Figure 2.1 reports the results of this difference test. Overall, there is no indication of a significant difference in the outcome variables. The enterprises are similar during the pre-tax treaty period, except only a marginal difference in the extent of innovation for enterprises in the two groups of countries.

It is important to acknowledge upfront that the tax treaties may be endogenous with respect to the foreign capital stock. However, this is not a significant threat to our identification since the timing or the extent of the treaty agreement is independent of the actions of small businesses.

\section{Figure 1.2.1 Average outcome variables of enterprises by country group}

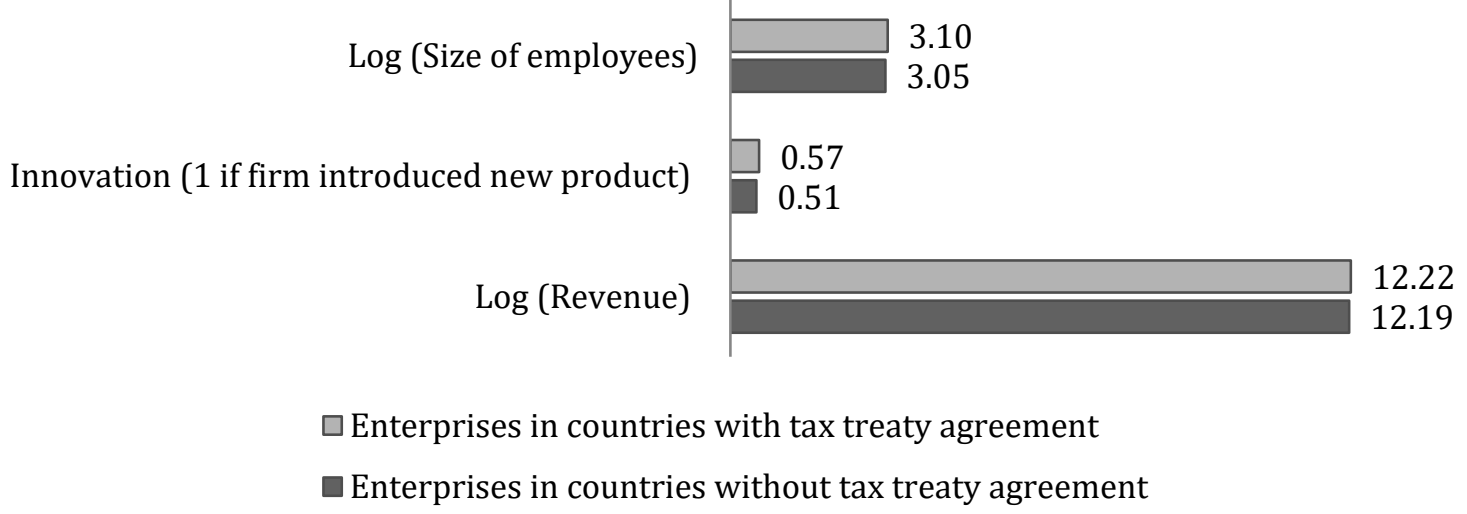

\section{Analysis and results}

\subsection{Tax treaties in Africa}

This section presents a graphical context of tax treaties in Africa. Figure 3.1 presents the sum of treaties still in force, those terminated, abandoned, those not in effect and those ratified as described in the ICTD data. From the figure, the agreement signed in 1947 between Sierra Leone, Ghana, and the United Kingdom was the earliest. The Ghana treaty is still in force. The other tax treaty in 1949, although terminated, was between Lesotho and the United Kingdom. The period 1950-1960 records increased treaty arrangements, with most being with other European countries such as Germany, Sweden, Norway and the United Kingdom. There are treaty agreements in this period between African countries, such as Sierra Leone and South Africa, South Africa and Tanzania, South Africa and Uganda, South Africa and Zambia, among others. All the tax treaties agreed in this period - apart from Sierra Leone and South Africa, South Africa and Zambia, and Malawi and the United Kingdom have already been terminated. 


\section{Figure 3.1 Number of treaties by African countries}

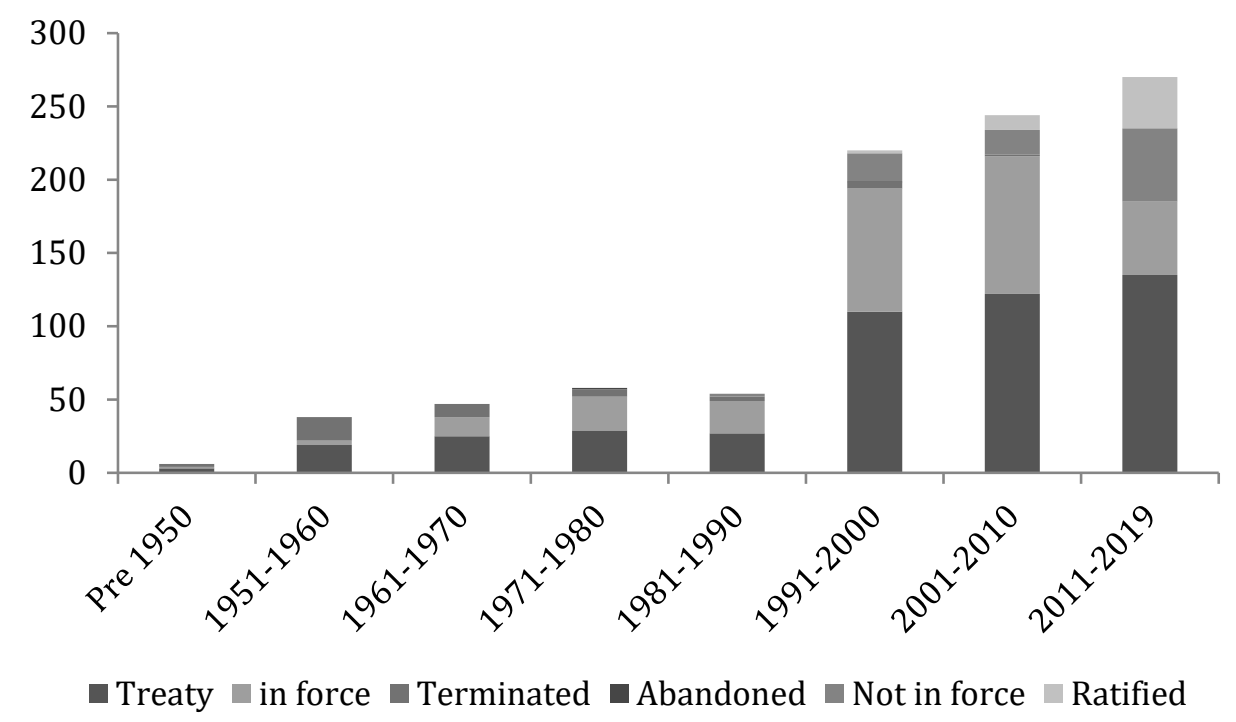

There were about 25 tax treaties between 1961-1970 and an increase in the number of those still in force (see Figure 3.1). Only 12 such agreements have been terminated, including those between Comoros Island and France, Egypt and Sudan, Malawi and the Netherlands, Liberia and Sweden, and South Africa and the United Kingdom. In 1971-1980, there were 29 tax treaties agreed upon, and 79 per cent of those treaties are still in force (see Figure 3.1). Only five of the 29 agreements are between two African countries: the rest of the tax treaties are between African countries and European countries like France, Romania, the United Kingdom, Norway, Italy, Spain, Netherlands, Sweden and Malta.

As seen from Figure 3.1, twenty-seven tax treaties were signed in the period 19811990. Three terminated, two are not in force, while the remaining 22 are still in effect. A significant increase was seen in the number of treaties in force for the period 1991-2000: 110 were signed, and 26 were either not in effect, terminated, or abandoned. The remaining 84 tax treaties are still in force, yet an increase in the number of tax treaties signed in 20012010 is seen, from 110 in the previous period to 122 . Out of these tax treaties, only 28 treaties were either not in force, terminated or ratified. The number of tax treaties in the 2011-2019 period increased to 135, but most tax treaties in this period (85 of them) are either ratified, not in force or abandoned.

The components of these treaties are in the ICTD dataset. Most of the agreements by African countries with length in months of construction of permanent establishment (PE) (UN= 6 months; OECD=12 months) consider either the UN or OECD model. Very few treaties are focused on other lengths, including Rwanda and Turkey in 2018 (not in force), Cameroon and UAE in 2017 (ratified), Ethiopia and Poland in 2015 (in force), Ethiopia and UAE in 2015, Kenya and Kuwait in 2013, Egypt and Ethiopia in 2011 (in force), Mauritius and Zambia in 2011 (in force), among others. These treaties have the length of time for taxing construction of PE at nine months. Some other tax treaties, such as Libya and UAE ratified in 2013 and Algeria and Mauritania in force in 2011, consider three months for this provision. Figure 3.2 also displays other issues featured in the tax treaties by African countries in the order of popularity. 


\section{Figure 3.2 Number of times these features appear in tax treaties in Africa}

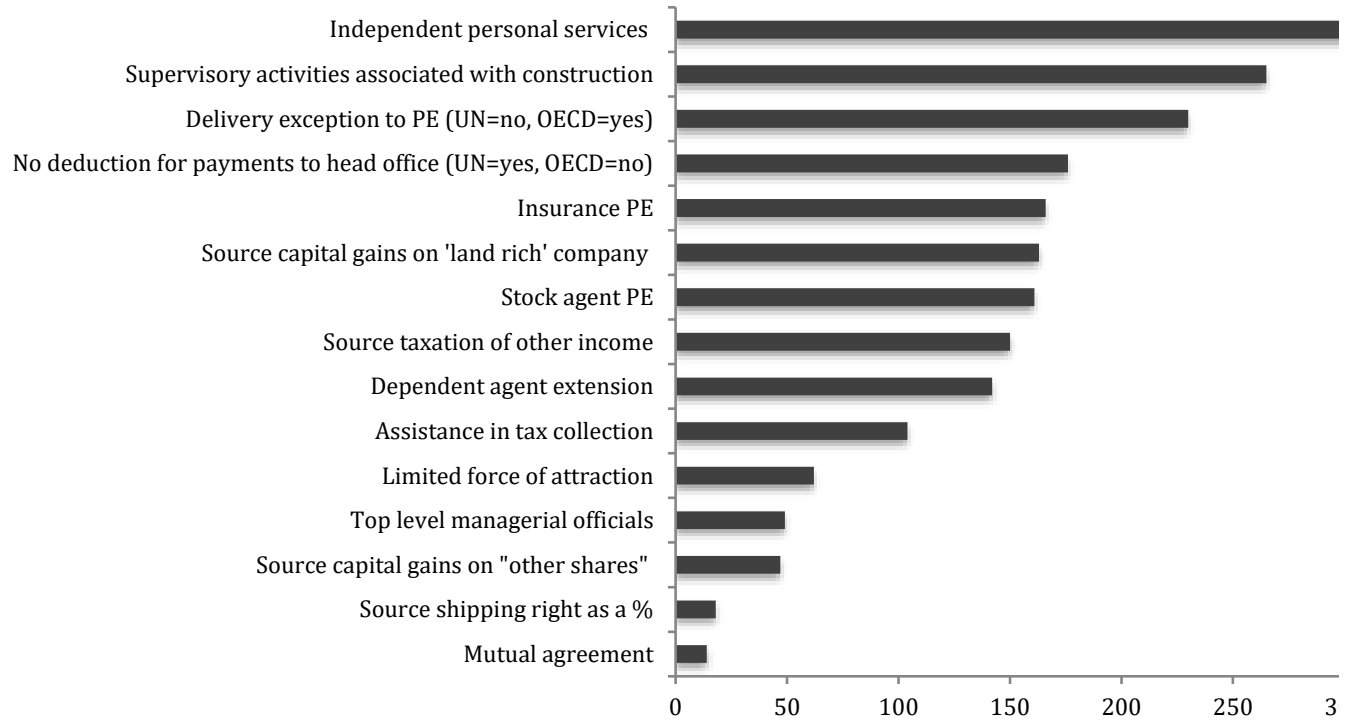

\subsection{Tax treaties and small business outcomes}

\subsubsection{The effect of tax treaties on small business outcomes}

This section explores the relationship between tax treaty ramifications and small business outcomes by applying the difference-in-difference estimation. The regression results in Table 3.2.1.1 considers the following dependent variables - the log value of total revenue (Panel A), a dummy for innovation (Panel B) and the log value of total employment (Panel C). Columns (1), (3) and (5) do not include the covariates, while columns (2), (4) and (6) adjust for the covariates. We will, therefore, focus the discussion on the most extensive model that adjusts for the covariates. The last row in Table 3.2.1.1 includes the mean outcome variables of small businesses in countries without the tax treaty's ratification.

The estimated association on the total revenue of the sampled firms in the Panel A column (2) indicates a negative association, which amounts to a 68 per cent significant decline from the mean for countries without the tax treaty enforcement. The coefficients are not sensitive to the inclusion of the control variables. In the model that considers innovation output in Panel B column (2), we also find an about 14.6 per cent significant reduction in the likelihood of introducing a new product for firms as a result of tax treaty ratification. The coefficients are also not sensitive to the inclusion of the control variables as we find a similar sign, magnitude and significant values for columns (3) and (4) of Panel B. Panel C column (6) report the effect of a tax treaty on the size of employees of the sampled enterprises. The result shows a significant negative association, which is equivalent to an about 48 per cent reduction from the mean of enterprises in the comparison group. Likewise, the coefficients are not sensitive to the inclusion of the control variables and the results in columns (5) and (6) are economically and statistically similar.

The estimated results are consistent with studies that have focused on the effect of a tax treaty on developing countries. For example, Beer and Loeprick (2021) estimate a sizeable 22 per cent reduction in government revenues of sampled sub-Saharan Africa (SSA) countries from a specific tax treaty agreement (i.e. investment hub treaties). Other studies raise concern regarding the negative consequences of tax treaties on SSA countries (e.g. Hearson 2015). 
Table 3.2.1.1 Impact of a treaty on small business outcomes

\begin{tabular}{|c|c|c|c|c|c|c|}
\hline & \multicolumn{2}{|c|}{ Panel A } & \multicolumn{2}{|c|}{ Panel B } & \multicolumn{2}{|c|}{ Panel C } \\
\hline & \multicolumn{2}{|c|}{ Revenue } & \multicolumn{2}{|c|}{$\begin{array}{c}\text { Innovation (1 if firm introduced new } \\
\text { product) }\end{array}$} & \multicolumn{2}{|c|}{ Size of employees } \\
\hline & [1] & [2] & [3] & [4] & [5] & [6] \\
\hline Tax Treaty (Post $\times$ Treaty) & $\begin{array}{c}- \\
1.610^{* * *} \\
(0.381) \\
\end{array}$ & $\begin{array}{c}- \\
1.145^{\star *} \\
(0.413)\end{array}$ & $\begin{array}{l}-0.272^{\star *} \\
(0.106)\end{array}$ & $\begin{array}{c}-0.146^{\star * *} \\
(0.045)\end{array}$ & $\begin{array}{c}-0.814^{* * *} \\
(0.264)\end{array}$ & $\begin{array}{l}-0.652^{\star *} \\
(0.288)\end{array}$ \\
\hline Control variables & No & Yes & No & Yes & No & Yes \\
\hline Country observation & 9 & 9 & 9 & 9 & 9 & 9 \\
\hline Firm observation & 5,328 & 3,159 & 5,000 & 3,200 & 6,227 & 3,733 \\
\hline Year FE & Yes & Yes & Yes & Yes & Yes & Yes \\
\hline Industry FE & Yes & Yes & Yes & Yes & Yes & Yes \\
\hline $\begin{array}{l}\text { Mean: Countries without } \\
\text { Treaty }\end{array}$ & 11.793 & 11.793 & 0.562 & 0.562 & 2.868 & 2.868 \\
\hline
\end{tabular}

Note: Total revenue and the size of employees are estimated in their logarithm form. Tax treaty implies the interaction term between dummy for treaty country and a dummy for post treaty ratification. In columns [3] and [4], we drop the direct effect of post treaty ratification dummy due to multicollinearity issues. The control variables earlier described in Section 2.2 are only included in columns 2, 4 and 6. Standard errors in parentheses are clustered at the country level. Probability values are * $p<$ $0.1 ;{ }^{* *} p<0.05 ;{ }^{* * *} p<0.01$.

\subsubsection{Correlation between tax treaty components and small business outcomes}

Next, we explore the correlation between some of the components of tax treaties and small business outcomes in Africa by relying on the repeated cross-section of the World Bank enterprise survey for 21 countries with data available across years ${ }^{4}$. We selectively considered the following components as key explanatory variables: (a) a dummy if the treaty considers the OECD model in delivering exception to permanent establishments and 0 if UN model ${ }^{5}$; (b) interest in withholding tax rate in \% $(O E C D=10)$; (c) royalties withholding tax rate in \% $(\mathrm{OECD}=0)$; (d) dummy if the treaty has source capital gains on 'land rich' company according to OECD and UN model ${ }^{6}$; (e) dummy if the treaty has source taxation of earnings by top-level managerial officials according to $\mathrm{UN}$ model and 0 if OECD model ${ }^{7}$; and (f) assistance in tax collection $(1=y e s)^{8}$. In each regression in Table 3.2.2.1, we control for the industry- and year-fixed effects and the standard errors are clustered at the country level.

These components are the ones with the most reportage and variation from the ICTD tax treaty dataset. Furthermore, we considered these components of tax treaties, noting that they specifically capture the subsidising (or otherwise) effects of tax treaties on the activities of multinationals (Davies, Norbäck and Tekin-Koru 2009; Hearson 2016).

We only discuss the most extensive estimate that controls for the size (asset value) and legal status of the sampled enterprises. However, the estimates do not change whether these covariates are included (or not) in the model. We find a 29 per cent significant decline in employee size with the inclusion of tax treaty components that align with the OECD model in delivering exceptions to permanent establishments (see Panel A Column 6). Likewise, the results in Column 4 of Panel D suggest that small businesses in tax treaty countries with

\footnotetext{
${ }^{4}$ The sampled countries are Algeria, Republic of Benin, Burundi, Cameroon, Congo Democratic Republic, Ethiopia, Gambia, Kenya, Lesotho, Madagascar, Malawi, Mali, Mauritania, Morocco, Mozambique, Namibia, Sierra Leone, South Africa, Swaziland, and Uganda. The sample period ranges 2005-2018.

${ }^{5}$ OECD model states that a building site or construction or installation project will constitute a PE, whereas the UN model states that a building site, a construction, assembly or installation project or supervisory activities in connection thereof will constitute a PE.

${ }^{6}$ See UN model Article 13(4)

7 See UN model Article 16(2)

${ }^{8}$ See UN model Article 27
} 
provisions for source capital gains for 'land rich' companies according to OECD and UN model see a 15.2 per cent decline in the likelihood of an enterprise introducing a new product (i.e. innovation). The adverse effect of these two components of tax treaties suggests that exceptions to permanent establishments and provisions for source capital gains could subsidise the flow and operations of multinational enterprises and could have a crowding-out effect on the activities of small businesses, seen by the decline in the size of employees and innovation.

The estimates from Column 2, Panel B, suggest an about 12.9 per cent increase in enterprises' total revenue with an additional increase in the rate for withholding tax charges on multinational enterprises. We also show from Column 4, Panel $\mathrm{C}$ that an additional increase in the interest in withholding tax rate on royalties leads to a 4 per cent increase in the likelihood of an enterprise to introduce a new product or be innovative. These effects on performance and innovation from an increase in withholding tax rates interest and on royalties could be because these provisions increase the cost of foreign-owned rivals' products and intellectual property - and hence competing products by indigenous enterprises becomes lower.

The estimates from Panel $D$ (Column 2) show a marginal negative effect on enterprises' total revenue, including source capital gains on 'land rich' companies according to the OECD and UN model. Overall, we do not find a significant effect for the inclusion of the tax treaty component that supports the UN model for source taxation of earnings by top-level management officials and assistance in tax collection.

Table 3.2.2.1 Correlational analysis - components of tax treaties and small business outcomes

\begin{tabular}{|c|c|c|c|c|c|c|}
\hline & \multicolumn{2}{|c|}{ Revenue } & \multicolumn{2}{|c|}{$\begin{array}{c}\text { Innovation (1 if firm } \\
\text { introduced new product) }\end{array}$} & \multicolumn{2}{|c|}{ Size of employees } \\
\hline & [1] & [2] & [3] & [4] & [5] & [6] \\
\hline \multicolumn{7}{|l|}{ Panel A } \\
\hline Exception to permanent establishments & $\begin{array}{c}-0.042 \\
(0.201)\end{array}$ & $\begin{array}{l}-0.066 \\
(0.228)\end{array}$ & $\begin{array}{c}-0.033 \\
(0.051)\end{array}$ & $\begin{array}{l}-0.038 \\
(0.050)\end{array}$ & $\begin{array}{c}- \\
0.260^{\star * *} \\
(0.085)\end{array}$ & $\begin{array}{c}-0.293^{* * *} \\
(0.067) \\
\end{array}$ \\
\hline Control variables & No & Yes & No & Yes & No & Yes \\
\hline Firm observation & 11,032 & 10,709 & 7,599 & 7,290 & 12,139 & 11,769 \\
\hline Year FE & Yes & Yes & Yes & Yes & Yes & Yes \\
\hline Country FE & Yes & Yes & Yes & Yes & Yes & Yes \\
\hline \multicolumn{7}{|l|}{ Panel B } \\
\hline Withholding tax rate: Interest WHT in \% & $\begin{array}{l}0.121^{* *} \\
(0.049)\end{array}$ & $\begin{array}{c}0.121^{* * *} \\
(0.042)\end{array}$ & $\begin{array}{l}-0.004 \\
(0.020) \\
\end{array}$ & $\begin{array}{l}-0.008 \\
(0.020) \\
\end{array}$ & $\begin{array}{l}-0.007 \\
(0.043)\end{array}$ & $\begin{array}{l}-0.015 \\
(0.036)\end{array}$ \\
\hline Control variables & No & Yes & No & Yes & No & Yes \\
\hline Firm observation & 11,032 & 10,709 & 7,599 & 7,290 & 12,139 & 11,769 \\
\hline Year FE & Yes & Yes & Yes & Yes & Yes & Yes \\
\hline Country FE & Yes & Yes & Yes & Yes & Yes & Yes \\
\hline \multicolumn{7}{|l|}{ Panel C } \\
\hline $\begin{array}{l}\text { Withholding tax rate: Royalties WHT in } \\
\%\end{array}$ & $\begin{array}{c}-0.004 \\
(0.094) \\
\end{array}$ & $\begin{array}{c}0.089 \\
(0.064) \\
\end{array}$ & $\begin{array}{l}0.025^{* *} \\
(0.012) \\
\end{array}$ & $\begin{array}{l}0.041^{\star * *} \\
(0.004)\end{array}$ & $\begin{array}{l}-0.054 \\
(0.044) \\
\end{array}$ & $\begin{array}{l}-0.015 \\
(0.036) \\
\end{array}$ \\
\hline Control variables & No & Yes & No & Yes & No & Yes \\
\hline Firm observation & 10,880 & 10,557 & 7,527 & 7,218 & 11,982 & 11,612 \\
\hline Year FE & Yes & Yes & Yes & Yes & Yes & Yes \\
\hline Country FE & Yes & Yes & Yes & Yes & Yes & Yes \\
\hline
\end{tabular}




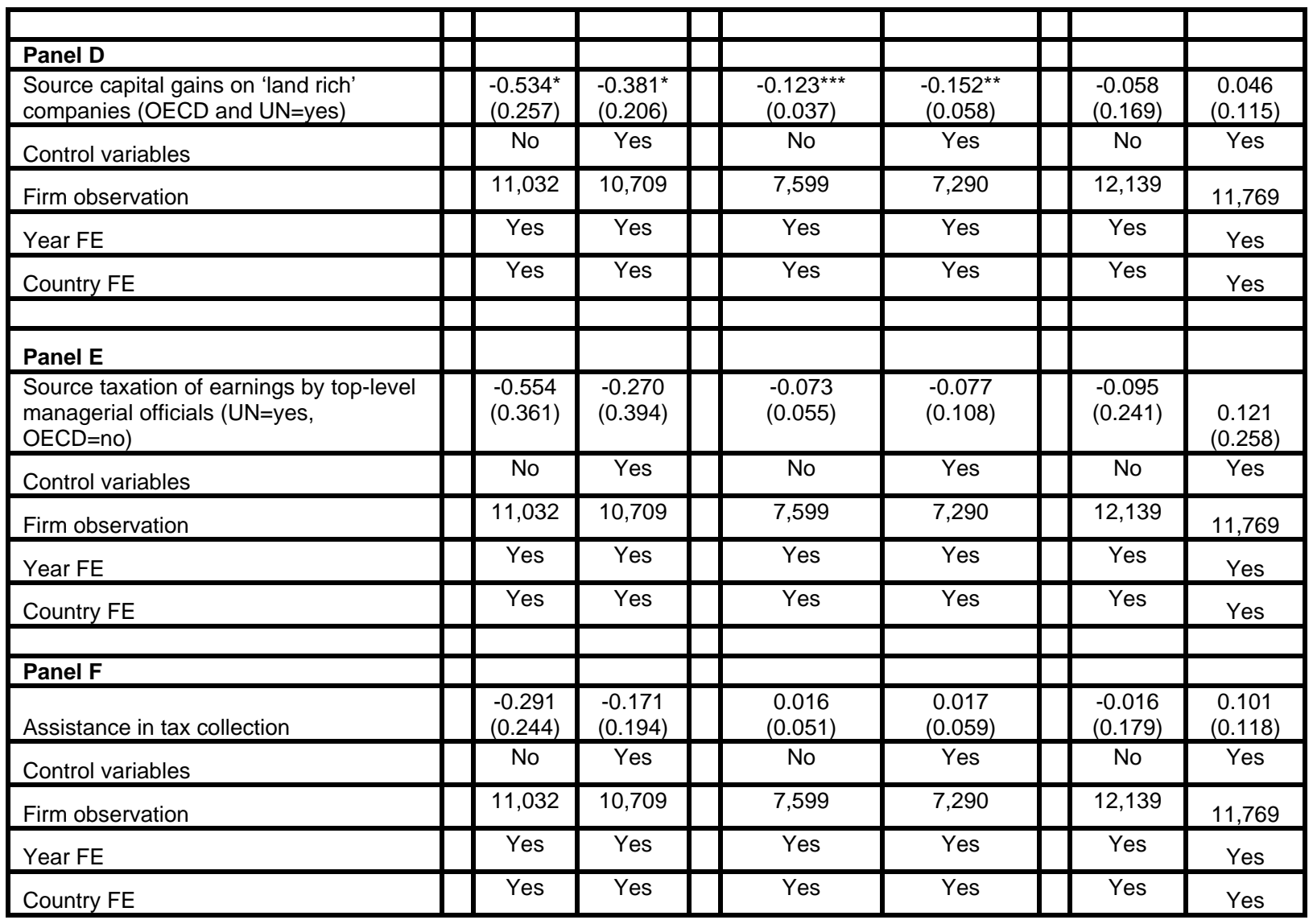

Note: Total revenue and the size of employees are estimated in their logarithm form. In columns [1], [3] and [5] are estimates without control variables, while columns [2], [4] and [6] include the control variables earlier described in Section 2.2. Standard errors in parentheses are clustered at the country-level. Probability values are ${ }^{*} p<0.1 ;{ }^{* *} p<0.05 ;{ }^{* *} p<0.01$.

\subsection{Additional robustness}

We first consider a different clustering level for the robustness check; that is, clustering at the industry-country level. This level of clustering is necessitated to check how the main result performs when considering a two-level sample aggregation. We find a consistent negative effect of a tax treaty on the three outcome variables we have considered.

Table 3.3.1 Impact of a treaty on small business outcomes (considering clustering at industry- and country-level)

\begin{tabular}{|c|c|c|c|c|c|c|}
\hline & \multicolumn{2}{|c|}{ Panel A } & \multicolumn{2}{|c|}{ Panel B } & \multicolumn{2}{|c|}{ Panel C } \\
\hline & \multicolumn{2}{|c|}{ Revenue } & \multicolumn{2}{|c|}{$\begin{array}{c}\text { Innovation (1 } 1 \text { if firm introduced new } \\
\text { product) }\end{array}$} & \multicolumn{2}{|c|}{ Size of employees } \\
\hline & [1] & [2] & [3] & [4] & [5] & {$[6]$} \\
\hline Tax treaty (Post $\times$ Treaty) & $\begin{array}{c}- \\
1.611^{\star \star \star} \\
(0.353)\end{array}$ & $\begin{array}{c}- \\
1.145^{\star \star} \\
(0.496) \\
\end{array}$ & $\begin{array}{l}-0.057^{\star \star} \\
(0.02)\end{array}$ & $\begin{array}{l}-0.146^{\star \star *} \\
(0.045)\end{array}$ & $\begin{array}{l}-0.814^{* \star *} \\
(0.236)\end{array}$ & $\begin{array}{l}-0.652^{* *} \\
(0.287) \\
\end{array}$ \\
\hline Control variables & No & Yes & No & Yes & No & Yes \\
\hline Country observation & 9 & 9 & 9 & 9 & 9 & 9 \\
\hline Firm observation & 5,328 & 3,159 & 5,000 & 3,200 & 6,227 & 3,733 \\
\hline Year FE & Yes & Yes & Yes & Yes & Yes & Yes \\
\hline Industry FE & Yes & Yes & Yes & Yes & Yes & Yes \\
\hline $\begin{array}{l}\text { Mean: Countries without } \\
\text { Treaty }\end{array}$ & 12.178 & 12.178 & 0.530 & 0.530 & 3.105 & 3.105 \\
\hline
\end{tabular}


The second robustness check is the re-estimation of the difference-in-difference model without the inclusion of firms from Malawi and Mali. These countries are only classified in the treatment group because they have significant economic cooperation with treaty countries apart from definite foreign investment flows. Therefore, we exclude them from the treatment group to check the consistency of the earlier results. As shown in Table 3.3.2, the signs of the estimates do not change and are economically similar to the earlier estimations in Table 3.2.2.1.

Table 3.3.2 Impact of a treaty on small business outcomes (excluding firms from Malawi and Mali)

\begin{tabular}{|c|c|c|c|c|c|c|}
\hline & \multicolumn{2}{|c|}{ Panel A } & \multicolumn{2}{|c|}{ Panel B } & \multicolumn{2}{|c|}{ Panel C } \\
\hline & \multicolumn{2}{|c|}{ Revenue } & \multicolumn{2}{|c|}{$\begin{array}{c}\text { Innovation (1 if firm introduced new } \\
\text { product) }\end{array}$} & \multicolumn{2}{|c|}{ Size of employees } \\
\hline & [1] & [2] & [3] & {$[4]$} & [5] & [6] \\
\hline Tax treaty (Post $\times$ Treaty) & $\begin{array}{c}- \\
1.075^{\star *} \\
(0.447)\end{array}$ & $\begin{array}{c}- \\
1.886^{*} \\
(1.050)\end{array}$ & $\begin{array}{l}-0.079^{* *} \\
(0.033)\end{array}$ & $\begin{array}{l}-0.236^{* * *} \\
(0.044)\end{array}$ & $\begin{array}{c}-0.637^{* *} \\
(0.311)\end{array}$ & $\begin{array}{l}-0.099 \\
(0.366)\end{array}$ \\
\hline Control variables & No & Yes & No & Yes & No & Yes \\
\hline Country observation & 6 & 6 & 6 & 6 & 6 & 6 \\
\hline Firm observation & 3,783 & 2,067 & 3,888 & 2,417 & 4,403 & 2,483 \\
\hline Year FE & Yes & Yes & Yes & Yes & Yes & Yes \\
\hline Industry FE & Yes & Yes & Yes & Yes & Yes & Yes \\
\hline $\begin{array}{l}\text { Mean: Countries without } \\
\text { Treaty }\end{array}$ & 12.178 & 12.178 & 0.530 & 0.530 & 3.105 & 3.105 \\
\hline
\end{tabular}

Note: The data for this analysis excludes firms from Malawi and Mali. Other notes are similar to those in Table 3.2.2.1.

As shown in Table A1.2 in the appendix, there are some significant differences in the baseline characteristic of enterprises in countries in the treatment and comparison group. For instance, from Table A1.2, we see that there are significant differences between firms in the treatment and comparison groups in the legal status (i.e., sole proprietor and limited liability company), ownership status, the experience of a top manager, age of enterprise, technology utilisation, obstacles from the external environment, access to overdraft and line of credit, the indicator of the value of total machinery, and the combined value of land and machinery. As a result of these differences in the characteristics of the sampled firms at the baseline, these initial conditions could have a separate influence on the subsequent changes in the estimated outcome. We apply the propensity score matching with the baseline data to address the observable heterogeneity in the initial conditions by ensuring the comparison group is similar to the treatment group and then applying the difference-in-difference estimation to the matched sample.

The matching that we estimated based on the observable characteristics of the enterprises is successful, as shown in Figure 3.3.1. The differences between firms in the treatment group and those in the comparison group are eliminated after the matching. The results of the difference-in-difference analysis on the matched data are presented in Table 3.3.3. The results show that the initial negative impact of a tax treaty on the different outcome variables (as presented in Panels $A-C$ ) is retained despite matching firms in the treatment and comparison groups. 
Figure 3.3.1 Propensity scores before and after the matching
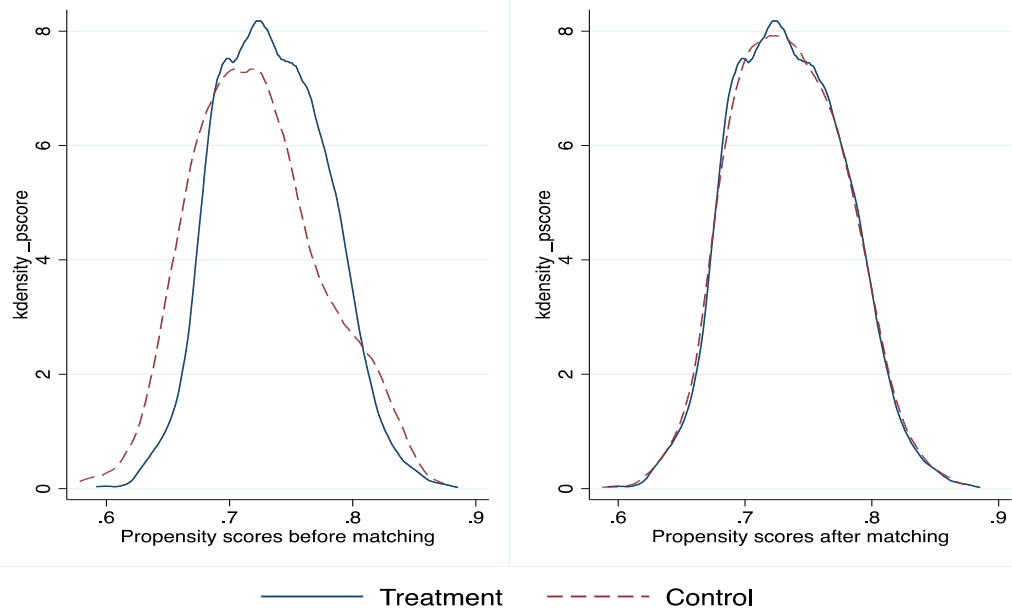

Note: Treatment and Control imply those countries with tax treaty ratification and those without any form of a tax treaty.

Table 3.3.3 Impact of a treaty on small business outcomes (using matched data)

\begin{tabular}{|c|c|c|c|c|c|c|}
\hline & \multicolumn{2}{|c|}{ Panel A } & \multicolumn{2}{|c|}{ Panel B } & \multicolumn{2}{|c|}{ Panel C } \\
\hline & \multicolumn{2}{|c|}{ Revenue } & \multicolumn{2}{|c|}{$\begin{array}{c}\text { Innovation (1 } 1 \text { if firm introduced new } \\
\text { product) }\end{array}$} & \multicolumn{2}{|c|}{ Size of employees } \\
\hline & [1] & [2] & [3] & {$[4]$} & {$[5]$} & {$[6]$} \\
\hline Tax treaty (Post $\times$ Treaty) & $\begin{array}{c}- \\
8.697^{\star * *} \\
(0.761)\end{array}$ & $\begin{array}{c}- \\
1.143^{* *} \\
(0.414)\end{array}$ & $\begin{array}{l}-0.884^{* * *} \\
(0.159)\end{array}$ & $\begin{array}{l}-0.146^{* * *} \\
(0.044)\end{array}$ & $\begin{array}{l}-1.574^{* * *} \\
(0.232)\end{array}$ & $\begin{array}{l}-0.652^{* *} \\
(0.289)\end{array}$ \\
\hline Control variables & No & Yes & No & Yes & No & Yes \\
\hline Country observation & 9 & 9 & 9 & 9 & 9 & 9 \\
\hline Firm observation & 3,158 & 3,158 & 3,199 & 3,199 & 3,732 & 3,732 \\
\hline Year FE & Yes & Yes & Yes & Yes & Yes & Yes \\
\hline Industry FE & Yes & Yes & Yes & Yes & Yes & Yes \\
\hline $\begin{array}{l}\text { Mean: Countries without } \\
\text { Treaty }\end{array}$ & 11.724 & 11.724 & 0.571 & 0.571 & 2.834 & 2.834 \\
\hline
\end{tabular}

Note: The data for this study are from the matched sample of firms in the treatment and comparison groups, which is based on observable characteristics. Other notes are similar to those in Table 3.2.2.1.

\subsection{Heterogeneous effects}

We examine whether the treatment effects vary by the characteristics of the enterprise. Of particular interest is the heterogeneity of effect by the size of the enterprise, internationalisation status and whether the enterprise is a subsidiary of a multinational. There are some documented observable differences in small business outcomes with foreign investment, depending on the size, internationalisation status and subsidiary of a multinational (Reyes 2018; Narula and Pineli 2019). One of the reasons it may be important to understand how different sizes of small businesses and their international status matter in determining the extent of the impact of tax treaties is that policymakers might be interested in whether treaties may have a differential impact on enterprises depending on these characteristics.

We explore this in Table A1.4, where we estimate separate outcome models for enterprises with an employee size greater than ten and less than 50 workers (small enterprises), and those with employee size greater than 51 and less than 250 (medium 
enterprises). We also explore in Table A1.5 a separate model for firms that are not internationally exposed and those that are internationally exposed based on having an international-quality certification by an internationally-recognised standard organisation. In Table A1.6, we test for heterogeneity by the subsidiary status of a multinational, noting a well-known difference in the impact of foreign investment presence across the enterprise's subsidiary status.

In the discussion of heterogeneity, we only focus on columns that adjust for the firmand macro-level control variables. We find from Table A1.4 the evidence of heterogeneity along with total revenue and the total size of the enterprise (using total employee size) dimension of firm' outcomes. Small enterprises face a more significant negative impact on these dimensions of outcomes from tax treaties than medium-sized firms. In terms of innovation, we find that medium-sized firms are significantly and negatively affected, unlike the coefficients of smaller firms that are negative but not significant. From Table A1.5, we also find a significant negative impact of a tax treaty on total revenue and innovation for firms with no internationalisation, unlike firms with some level of internationalisation. However, we do not find any heterogeneity effect on total employment by whether the firm has an international certification or not. Finally, we do not find any evidence of heterogeneity based on the sampled firms' subsidiary status along any of the different dimensions of the outcome variables.

\section{Conclusion}

There is a growing literature on tax treaties and their consequences on developing countries. Constrained by credible datasets, some of the questions regarding the implications of tax treaties between developing countries and other countries - mostly country of origin for foreign capital and investment - have remained mostly unanswered. Some of the previous studies have provided evidence regarding the effect of treaties and foreign investment, with scant evidence regarding its effect on small businesses, which are essential sources of technological innovation, job creation and overall industrial growth. Moreover, these small businesses are also the most affected by FDI inflow that could arise from tax treaties.

Our main findings present evidence that there are adverse small business outcomes (including revenues, innovation and growth) from ratified tax treaties between developing African countries and other capital 'rich' countries. These negative relationships are seen from firm-level data across nine countries in the Sub-Sahara African region. Some heterogeneity in effect exists by the size of the enterprises and the extent of their internationalisation links.

The likely explanation for the negative effect between tax treaties and small business outcomes could be due to intense foreign competition from foreign investment flows induced by the treaty ratification or the negative impact of tax treaties on host-country tax revenues that subsequently leads to a decline in the provision of public goods required for small business growth, among others. It is left for future studies to actually determine the extent to which these channels hold in explaining the effect seen in this paper. 


\section{References}

Agbloyor, E. K., Abor, J. Y., Adjasi, C. K. and Yawson, A. (2014) 'Private capital flows and economic growth in Africa: The role of domestic financial markets', Journal of International Financial Markets, Institutions and Money 30: 137-152

Ayyagari, M., Juarros, P., Peria, M.S. and Singh, S. (2016) Access to Finance and Job Growth: Firm-Level Evidence across Developing Countries, World Bank Policy Research Working Paper, WPS7604, World Bank: Washington

Barthel, F., Busse, M., Krever, R. and Neumayer, E. (2010) 'The relationship between double taxation treaties and foreign direct investment', in M. Lang, P. Pistone, J. Schuch, C. Staringer, A. Storck and M. Zagler (eds), Tax Treaties: Views From The BridgeBuilding Bridges Between Law And Economics, Amsterdam: IBFD

Beer, S., and Loeprick, J. (2021) 'Too high a price? Tax treaties with investment hubs in SubSaharan Africa', International Tax and Public Finance 28.1: 113-153

Blonigen B., Oldenski, L. and Sly, N. (2014) 'The Differential Effects of Bilateral Tax Treaties', American Economic Journal: Economic Policy 6: 1-18

Castillo-Murciego, Á. and López-Laborda, J. (2019) 'The effect of Double Taxation Treaties and Territorial Tax Systems on Foreign Direct Investment: evidence for Spain', Economics 13.1: 1-33, http://dx.doi.org/10.5018/economics-ejournal.ja.2019-22

Davies, R. B., Norbäck, P. J. and Tekin-Koru, A. (2009) 'The effect of tax treaties on multinational firms: new evidence from microdata', The World Economy 32.1: 77110

Davies, R. (2004) 'Tax treaties and foreign direct investment: Potential versus performance', International Tax and Public Finance 11: 775-802

Egger, P. and Merlo, V. (2011) 'Statutory Corporate Tax Rates and Double-Taxation Treaties as Determinants of Multinational Firm Activity', Public Finance Analysis 67.2: 145170

Egger, P., Larch, M., Pfaffermayr, M. and Winner, H. (2006). 'The impact of endogenous tax treaties on foreign direct investment: theory and evidence', Canadian Journal of Economics 39.3: 901-931

Elu, J. U. and Price, G. N. (2010) 'Does China transfer productivity enhancing technology to Sub-Saharan Africa? Evidence from manufacturing firms', African Development Review 22: 587-598

Falk, M. (2015) 'The Relationship Between FDI Through Backward Linkages and Technological Innovations of Local Firms: Evidence for Emerging Economies', Eastern European Economies 53.5: 424-438

Gorg, H. and Strobl, E. (2001) 'Multinational Companies and Productivity Spillovers: a Metaanalysis', Economic Journal 111: 723-739

Gui-Diby, S. L. and Renard, M.F. (2015) 'Foreign Direct Investment Inflows and the Industrialisation of Africa', World Development 74: 43-57 
Haltiwanger, J., Jarmin, R. S. and Miranda, J. (2013) 'Who Creates Jobs? Small versus Large versus Young', Review of Economics and Statistics 95.2: 347-361

Hearson, M. (2015) Tax treaties in sub-Saharan Africa: a critical review, Nairobi: Tax Justice Network - Africa

Hearson, M. (2016) Measuring Tax Treaty Negotiation Outcomes: the ActionAid Tax Treaties Dataset, International Centre for Tax and Development Working Paper 47, https://opendocs.ids.ac.uk/opendocs/bitstream/handle/123456789/11206/ICTD_WP47.p df

Hearson, M. (2018) 'When do Developing Countries Negotiate away their Corporate Tax Base?', Journal of International Development 30: 233-255, doi: 10.1002/jid.3351

Hsieh, C. and Klenow. P. J. (2014) 'The Life Cycle of Plants in India and Mexico', The Quarterly Journal of Economics 129.3: 1035-1084

Janský, P. and Šedivý, M. (2018) 'Estimating the revenue costs of tax treaties in developing countries', The World Economy 42.6: 1828-1849

Kaya, Y. (2010) 'Globalisation and industrialisation in 64 developing countries, 19802003', Social Forces 88.3: 1153-1182

Lipsey, R. E. (2004) 'Home- and Host-Country Effects of Foreign Direct Investment', in R. E. Baldwin and L. A. Winters (Eds.), Challenges to Globalisation: Analysing the Economics, Chicago: University of Chicago Press.

McKenzie, D. (2017) 'Identifying and Spurring High-Growth Entrepreneurship: Experimental Evidence from a Business Plan Competition', American Economic Review 107.8: 2278-2307

Nam, J. B. and Young, A. S. (2004) 'Multinational Corporations and Host Country Receptivity: Perceptions from Three Asian Countries', Multinational Business Review 12: 17-36

Narula, R. and Pineli, A. (2019) 'Improving the developmental impact of multinational enterprises: policy and research challenges', Journal of Industrial and Business Economics 46: 1-24

Neumayer, E. (2007) 'Do double taxation treaties increase foreign direct investment to developing countries?', The Journal of Development Studies 43.8: 1501-1519

Newman, C., Page, J., Rand, J., Shimeles, A., Soderbom, M. and Tarp, F. (2016) Manufacturing Transformation Comparative Studies of Industrial Development in Africa and Emerging Asia, Oxford: Oxford University Press

Petkova, K., Stasio, A. and Zagler, M. (2020) 'On the relevance of double tax treaties', International Tax and Public Finance 27.3: 575-605

Quak, E. and Timmis, H. (2018) 'Double Taxation Agreements and Developing Countries', K4D Helpdesk Report, Brighton: IDS

Reyes, J. (2017) 'Effects of FDI on High-Growth Firms in Developing Countries', Global Investment Competitiveness Report 2017/2018, doi: 10.1596/978-1-4648-1175-3 
Reyes, J.D. (2018) 'Effects of FDI on High-Growth Firms in Developing Countries', Global Investment Competitiveness Report, doi: 10.1596/978-1-4648-1175-3, http://pubdocs.worldbank.org/en/687611508856691875/GICR-02.pdf

Royal Norwegian Embassy (2019), Doing Business in Malawi, https://www.norway.no/en/malawi/services-info/doing-business-in-malawi/

The Economist (2014) Morocco consolidates foothold in Sub-Saharan Africa, http://country.eiu.com/article.aspx ?articleid=311680815\&Country=Morocco\&topic=E conomy_1

Thompson, P. and Zang, W. (2018) 'The Foreign Business and Domestic Enterprise Relationship: Its Implications for Local Entrepreneurial Resilience', Local Economy: The Journal of the Local Economy Policy Unit 33.1: 10-39 


\section{Appendices}

\section{Appendix 1}

Table A1.1 Sample countries by survey years

\begin{tabular}{|l|c|c|}
\hline & Pre & Post \\
\hline Treatment & & \\
\hline Mali & 2010 & 2016 \\
\hline Kenya & 2007 & 2018 \\
\hline Malawi & 2009 & 2014 \\
\hline Lesotho & 2009 & 2016 \\
\hline Comparison & & \\
\hline Sierra Leone & 2009 & 2017 \\
\hline Swaziland & 2006 & 2016 \\
\hline Uganda & 2006 & 2013 \\
\hline Mauritania & 2006 & 2014 \\
\hline Namibia & 2006 & 2014 \\
\hline
\end{tabular}

Note: Survey periods are from World Bank Enterprise Surveys

Table A1.2 Test of difference in firms' characteristics at baseline

\begin{tabular}{|c|c|c|c|}
\hline Firm Characteristics & $\begin{array}{c}\text { Comparison } \\
\text { [Countries without tax treaty) }\end{array}$ & $\begin{array}{c}\text { Treatment [Countries } \\
\text { with tax treaty] }\end{array}$ & $\begin{array}{c}\mathrm{T}- \\
\text { statistics } \\
\end{array}$ \\
\hline \multicolumn{4}{|l|}{ Outcome variables } \\
\hline Log total revenue & 12.188 & 12.222 & -0.332 \\
\hline Innovation - introduced a new product & 0.511 & 0.565 & $-1.979^{*}$ \\
\hline Log total employment & 3.054 & 3.098 & -0.775 \\
\hline \multicolumn{4}{|l|}{ Other Firm-level Characteristics } \\
\hline Formal training & 1.323 & 1.547 & $-1.737^{\star}$ \\
\hline Legal status - Sole proprietor & 0.401 & 0.517 & $-5.343^{\star \star \star}$ \\
\hline Legal status - Limited liability company & 0.469 & 0.333 & $6.523^{\star * *}$ \\
\hline Ownership status - Non-government owned & 0.991 & 0.978 & $2.295^{* \star}$ \\
\hline Gender of top manager - if female & 0.2169 & 0.244 & -1.323 \\
\hline Years of experience of top manager in industry & 11.586 & 12.613 & $-2.588^{\star * *}$ \\
\hline Age of enterprise & 13.407 & 14.608 & $-2.139^{* *}$ \\
\hline Registration status of enterprise & 0.866 & 0.833 & 1.026 \\
\hline Exporting status & 0.151 & 0.159 & -0.507 \\
\hline Technology utilisation of the firm & 0.144 & 0.204 & $-3.496^{\star \star \star}$ \\
\hline External environment & 0.998 & 0.931 & $7.067^{* \star \star}$ \\
\hline Access to overdraft & 0.319 & 0.375 & $-2.681^{\star \star *}$ \\
\hline Access to line of credit & 0.234 & 0.296 & $-3.142^{* * *}$ \\
\hline Log value of total land & 4.280 & 4.488 & -0.758 \\
\hline Log value of total machinery & 9.556 & 7.953 & $6.922^{* * *}$ \\
\hline Asset valuation & 9.836 & 4.893 & $20.761^{* \star \star}$ \\
\hline
\end{tabular}


Note: We include the disaggregated asset values in the test of a difference since there are no issues of multicollinearity in the test of difference, unlike the regression analysis. Probability values are $p<0.1 ; p<0.05 ; p<0.01$. The values that are presented are the mean of the variables.

Table A1.3 Fixed effect regression - tax treaty and foreign investment

\begin{tabular}{|c|c|c|c|c|c|c|}
\hline & \multicolumn{2}{|c|}{ Panel A } & \multicolumn{2}{|c|}{ Panel B } & \multicolumn{2}{|c|}{ Panel C } \\
\hline & Foreign ir & stment to & Portfolio i & 'estment & $\begin{array}{r}\text { Foreign inv } \\
\text { cap }\end{array}$ & $\begin{array}{l}\text { gross fixed } \\
\text { tion }\end{array}$ \\
\hline & [1] & [2] & [3] & [4] & [5] & [6] \\
\hline Tax treaty (Post $\times$ Treaty) & $\begin{array}{c}2.281^{* \star *} \\
(0.043)\end{array}$ & $\begin{array}{c}3.793^{* * *} \\
(0.051)\end{array}$ & $\begin{array}{c}14.476^{\star * *} \\
(0.288)\end{array}$ & $\begin{array}{c}0.335^{\star \star \star} \\
(0.122)\end{array}$ & $\begin{array}{c}33.996^{\star * *} \\
(0.254)\end{array}$ & $\begin{array}{c}19.916^{\star * *} \\
(0.331)\end{array}$ \\
\hline Control variable & No & Yes & No & Yes & No & Yes \\
\hline Country observation & 9 & 9 & 9 & 9 & 9 & 9 \\
\hline Firm observation & 6,625 & 6,625 & 3,448 & 3,448 & 5,624 & 5,624 \\
\hline FE & Yes & Yes & Yes & Yes & Yes & Yes \\
\hline Mean: Sample without treaty & 6.580 & 6.580 & 17.643 & 17.643 & 15.420 & 15.420 \\
\hline
\end{tabular}

Note: These observations were taken for all firms in the sample for nine countries. The dependent variables are the net inflow of foreign direct investment as a percentage of GDP, net portfolio investment at current US\$ (log) and foreign direct investment as a percentage of gross fixed capital formation. Data for the first two indicators of foreign investment are obtained from the World Bank World Development Indicators, while data for the third indicator is obtained from the UNCTAD statistics. Columns (2), (4), and (6) include the control variables - the logarithm value of gross domestic product per capita and inflation rate. Columns (1), (3), and (5) are estimates without including these control variables. Standard errors are in parentheses. The probability values are $^{* * *} p<0.01$

\section{Table A1.4 Heterogeneity by size of domestic firms}

\begin{tabular}{|c|c|c|c|c|c|c|c|c|c|c|c|c|}
\hline & \multicolumn{6}{|c|}{ Panel A: Firms with Employee Size $>=10$ and $<=50$} & \multicolumn{6}{|c|}{$\begin{array}{l}\text { Panel B: Firms with Employee Size }>=51 \text { and } \\
\qquad<=250\end{array}$} \\
\hline & \multicolumn{2}{|c|}{ Revenue } & \multicolumn{2}{|c|}{$\begin{array}{c}\text { Innovation (1 if } \\
\text { firm } \\
\text { introduced } \\
\text { new product) }\end{array}$} & \multicolumn{2}{|c|}{$\begin{array}{l}\text { Size of } \\
\text { employees }\end{array}$} & \multicolumn{2}{|c|}{ Revenue } & \multicolumn{2}{|c|}{$\begin{array}{l}\text { Innovation (1 if } \\
\text { firm introduced } \\
\text { new product) }\end{array}$} & \multicolumn{2}{|c|}{$\begin{array}{c}\text { Size of } \\
\text { employees }\end{array}$} \\
\hline & [1] & [2] & [3] & {$[4]$} & [5] & [6] & [7] & [8] & [9] & [10] & [11] & [12] \\
\hline $\begin{array}{l}\text { Tax } \\
\text { treaty } \\
\text { (Post } x \\
\text { Treaty) } \\
\end{array}$ & $\begin{array}{c}- \\
0.850^{*} \\
(0.264 \\
\left(\begin{array}{c}* * \\
\end{array}\right.\end{array}$ & $\begin{array}{c}- \\
1.045^{*} \\
(0.090 \\
)^{* *}\end{array}$ & $\begin{array}{c}- \\
0.256 \\
(0.16 \\
1)\end{array}$ & $\begin{array}{c}- \\
0.154 \\
(0.09 \\
5)\end{array}$ & $\begin{array}{c}- \\
0.149 \\
* * \\
(0.07 \\
2)\end{array}$ & $\begin{array}{c}- \\
0.423^{*} \\
* * \\
(0.126 \\
)\end{array}$ & $\begin{array}{c}- \\
1.043 \\
* \\
(0.58 \\
2) \\
\end{array}$ & $\begin{array}{c}- \\
0.768 \\
(0.66 \\
7)\end{array}$ & $\begin{array}{c}- \\
0.141 \\
(0.14 \\
7)\end{array}$ & $\begin{array}{c}- \\
0.412^{*} \\
* * \\
(0.091 \\
)^{* *}\end{array}$ & $\begin{array}{c}- \\
0.097 \\
(0.20 \\
1)\end{array}$ & $\begin{array}{c}- \\
0.160 \\
(0.31 \\
1)\end{array}$ \\
\hline $\begin{array}{l}\text { Control } \\
\text { variables }\end{array}$ & No & Yes & No & Yes & No & Yes & No & Yes & No & Yes & No & Yes \\
\hline $\begin{array}{l}\text { Country } \\
\text { observati } \\
\text { on }\end{array}$ & 9 & 9 & 9 & 9 & 9 & 9 & 9 & 9 & 9 & 9 & 9 & 9 \\
\hline $\begin{array}{l}\text { Firm } \\
\text { observati } \\
\text { on }\end{array}$ & 2,012 & 1,160 & 1,904 & 1,181 & 2,367 & 1,389 & 1,177 & 627 & 1,200 & 669 & 1,291 & 703 \\
\hline Year FE & Yes & Yes & Yes & Yes & Yes & Yes & Yes & Yes & Yes & Yes & Yes & Yes \\
\hline $\begin{array}{l}\text { Industry } \\
\text { FE }\end{array}$ & Yes & Yes & Yes & Yes & Yes & Yes & Yes & Yes & Yes & Yes & Yes & Yes \\
\hline $\begin{array}{l}\text { Mean: } \\
\text { Countries } \\
\text { without } \\
\text { treaty }\end{array}$ & 12.416 & $\begin{array}{c}12.41 \\
6\end{array}$ & 0.542 & 0.542 & 3.111 & 3.111 & $\begin{array}{c}14.75 \\
8\end{array}$ & $\begin{array}{c}14.75 \\
8\end{array}$ & 0.632 & 0.632 & 5.011 & 5.011 \\
\hline
\end{tabular}

Note: This heterogeneity is only observed for firms with an employee size greater than ten and less than 50, which we call small firms, and those with employees greater than 51 and less than 250, which we classify as medium-size firms based on the OECD firm classification. The tax treaty implies the interaction term between dummy for treaty country and a dummy for post treaty ratification. In columns [3] and [4], and [9] and [10], the direct effect of post treaty ratification dummy is dropped due to multicollinearity issues. The control variables are those included in Table 3.2.21. Standard errors in parentheses are clustered at the country level. Probability values are ${ }^{*} p<0.1 ;{ }^{* *} p<0.05 ;{ }^{* *} p<0.01$. 
Table A1.5 Heterogeneity by internationalisation status of domestic firms

\begin{tabular}{|c|c|c|c|c|c|c|c|c|c|c|c|c|}
\hline & \multicolumn{6}{|c|}{ Panel A: Firms with No Internationalisation } & \multicolumn{6}{|c|}{ Panel B: Firms with Internationalisation } \\
\hline & \multicolumn{2}{|c|}{ Revenue } & \multicolumn{2}{|c|}{$\begin{array}{l}\text { Innovation (1 if } \\
\text { firm introduced } \\
\text { new product) }\end{array}$} & \multicolumn{2}{|c|}{$\begin{array}{c}\text { Size of } \\
\text { employees }\end{array}$} & \multicolumn{2}{|c|}{ Revenue } & \multicolumn{2}{|c|}{$\begin{array}{c}\text { Innovation (1 if } \\
\text { firm } \\
\text { introduced } \\
\text { new product) }\end{array}$} & \multicolumn{2}{|c|}{$\begin{array}{l}\text { Size of } \\
\text { employees }\end{array}$} \\
\hline & [1] & [2] & [3] & [4] & [5] & {$[6]$} & [7] & [8] & [9] & {$[10]$} & [11] & [12] \\
\hline $\begin{array}{l}\text { Tax } \\
\text { treaty } \\
\text { (Post } x \\
\text { Treaty) }\end{array}$ & $\begin{array}{c}- \\
1.192^{*} \\
* * \\
(0.339 \\
)\end{array}$ & $\begin{array}{c}- \\
1.322^{*} \\
* * \\
(0.405 \\
)\end{array}$ & $\begin{array}{c}- \\
0.276^{*} \\
(0.093 \\
) \\
\end{array}$ & $\begin{array}{c}- \\
0.129^{*} \\
* * \\
(0.044 \\
)\end{array}$ & $\begin{array}{c}- \\
0.583^{*} \\
* * \\
(0.153 \\
\quad \\
\end{array}$ & $\begin{array}{c}- \\
0.406 \\
(0.28 \\
8)\end{array}$ & $\begin{array}{c}- \\
0.619 \\
(0.49 \\
5)\end{array}$ & $\begin{array}{c}- \\
1.329 \\
(1.21 \\
6)\end{array}$ & $\begin{array}{c}- \\
0.156 \\
(0.09 \\
2)\end{array}$ & $\begin{array}{c}- \\
0.133 \\
* \\
(0.07 \\
0) \\
\end{array}$ & $\begin{array}{c}- \\
0.050 \\
(0.23 \\
8)\end{array}$ & $\begin{array}{c}- \\
0.237 \\
(0.95 \\
9)\end{array}$ \\
\hline $\begin{array}{c}\text { Control } \\
\text { variables }\end{array}$ & No & Yes & No & Yes & No & Yes & No & Yes & No & Yes & No & Yes \\
\hline $\begin{array}{c}\text { Country } \\
\text { observati } \\
\text { on } \\
\end{array}$ & 9 & 9 & 9 & 9 & 9 & 9 & 9 & 9 & 9 & 9 & 9 & 9 \\
\hline $\begin{array}{c}\text { Firm } \\
\text { observati } \\
\text { on }\end{array}$ & 4,275 & 2,548 & 3,947 & 2,576 & 4,929 & 2,992 & 842 & 482 & 790 & 470 & 995 & 571 \\
\hline Year FE & Yes & Yes & Yes & Yes & Yes & Yes & Yes & Yes & Yes & Yes & Yes & Yes \\
\hline $\begin{array}{c}\text { Industry } \\
\mathrm{FE}\end{array}$ & Yes & Yes & Yes & Yes & Yes & Yes & Yes & Yes & Yes & Yes & Yes & Yes \\
\hline $\begin{array}{l}\text { Mean: } \\
\text { Countrie } \\
\text { s without } \\
\text { treaty }\end{array}$ & $\begin{array}{c}11.85 \\
0\end{array}$ & $\begin{array}{c}11.85 \\
0\end{array}$ & 0.505 & 0.505 & 2.846 & 2.846 & $\begin{array}{c}13.96 \\
1\end{array}$ & $\begin{array}{c}13.96 \\
1\end{array}$ & 0.668 & 0.668 & 3.976 & 3.976 \\
\hline
\end{tabular}

Note: This heterogeneity is only observed for firms who report no international standard certification (i.e., not internationalised) and those with international certification, which we call internationalised. The tax treaty, as usual, implies the interaction term between dummy for treaty country and a dummy for post treaty ratification. In columns [3] and [4], and [9] and [10], the direct effect of post treaty ratification dummy is dropped due to multicollinearity issues. The control variables are those included in Table 3.2.2.1. Standard errors in parentheses are clustered at the country level. Probability values are ${ }^{*} p<0.1 ;{ }^{* *} p<0.05 ;{ }^{* * *} p$ $<0.01$ 
Table A1.6 Heterogeneity by subsidiary status of domestic firms

\begin{tabular}{|c|c|c|c|c|c|c|c|c|c|c|c|c|}
\hline & \multicolumn{6}{|c|}{ Panel A: Non-subsidiary Firms } & \multicolumn{6}{|c|}{ Panel B: Subsidiary Firms } \\
\hline & \multicolumn{2}{|c|}{ Revenue } & \multicolumn{2}{|c|}{$\begin{array}{l}\text { Innovation (1 if } \\
\text { firm introduced } \\
\text { new product) }\end{array}$} & \multicolumn{2}{|c|}{$\begin{array}{l}\text { Size of } \\
\text { employees }\end{array}$} & \multicolumn{2}{|c|}{ Revenue } & \multicolumn{2}{|c|}{$\begin{array}{l}\text { Innovation (1 if } \\
\text { firm introduced } \\
\text { new product) }\end{array}$} & \multicolumn{2}{|c|}{$\begin{array}{l}\text { Size of } \\
\text { employees }\end{array}$} \\
\hline & [1] & [2] & {$[3]$} & [4] & [5] & [6] & [7] & [8] & {$[9]$} & {$[10]$} & [11] & [12] \\
\hline $\begin{array}{c}\text { Tax } \\
\text { treaty } \\
\text { (Post } x \\
\text { Treaty) }\end{array}$ & $\begin{array}{c}- \\
1.373^{*} \\
* * \\
(0.361 \\
)\end{array}$ & $\begin{array}{c}-\overline{-} \\
0.988 \\
* \star \\
(0.42 \\
6)\end{array}$ & $\begin{array}{c}-\overline{0} \\
0.316^{*} \\
(0.090 \\
{ }_{* *}^{0.09}\end{array}$ & $\begin{array}{c}- \\
0.285^{*} \\
\left(\begin{array}{c}0.056 \\
)\end{array}\right.\end{array}$ & $\begin{array}{c}-\overline{-} \\
0.629^{*} \\
{ }_{* *}^{0.206} \\
{ }^{0.2}\end{array}$ & $\begin{array}{c}-\bar{c} \\
0.444 \\
* \star \\
(0.22 \\
2)\end{array}$ & $\begin{array}{c}- \\
1.402^{*} \\
(0.355 \\
(0 . \\
)\end{array}$ & $\begin{array}{c}-\overline{-} \\
2.480 \\
* * \\
(0.91 \\
0)\end{array}$ & $\begin{array}{c}- \\
0.114 \\
(0.18 \\
7)\end{array}$ & $\begin{array}{c}- \\
0.254^{*} \\
\star 0 * \\
(0.080 \\
)\end{array}$ & $\begin{array}{c}- \\
0.220 \\
(0.50 \\
2)\end{array}$ & $\begin{array}{c}- \\
0.650 \\
* * \\
(0.29 \\
4)\end{array}$ \\
\hline $\begin{array}{c}\text { Control } \\
\text { variables }\end{array}$ & No & Yes & No & Yes & No & Yes & No & Yes & No & Yes & No & Yes \\
\hline $\begin{array}{l}\text { Country } \\
\text { observati } \\
\text { on }\end{array}$ & 9 & 9 & 9 & 9 & 9 & 9 & 9 & 9 & 9 & 9 & 9 & 9 \\
\hline $\begin{array}{c}\text { Firm } \\
\text { observati } \\
\text { on } \\
\end{array}$ & 4,173 & 2,498 & 3,849 & 2,490 & 4,857 & 2,949 & 1,155 & 661 & 1,151 & 710 & 1,370 & 784 \\
\hline Year FE & Yes & Yes & Yes & Yes & Yes & Yes & Yes & Yes & Yes & Yes & Yes & Yes \\
\hline $\begin{array}{l}\text { Industry } \\
\text { FE }\end{array}$ & Yes & Yes & Yes & Yes & Yes & Yes & Yes & Yes & Yes & Yes & Yes & Yes \\
\hline $\begin{array}{l}\text { Mean: } \\
\text { Countrie } \\
\text { s without } \\
\text { treaty }\end{array}$ & $\begin{array}{c}11.95 \\
8\end{array}$ & $\begin{array}{c}11.95 \\
8\end{array}$ & 0.527 & 0.527 & 2.920 & 2.920 & $\begin{array}{c}13.96 \\
1\end{array}$ & $\begin{array}{c}13.96 \\
1\end{array}$ & 0.668 & 0.668 & 3.976 & 3.976 \\
\hline
\end{tabular}

Note: We observe the heterogeneity for firms that report their subsidiary status. It includes firms that are subsidiaries or part of larger cooperation with headquarters abroad. The tax treaty, again, implies the interaction term between dummy for treaty country and a dummy for post treaty ratification. In columns [3] and [4], and [9] and [10], the direct effect of post treaty ratification dummy is dropped due to multicollinearity issues. The control variables are those included in Table 3.2.2.1. We cluster the standard errors in parentheses at the country level. Probability values are ${ }^{*} p<0.1 ;{ }^{* *} p<0.05 ;{ }^{* *} p<0.01$.

Figure A1.1 How treaties affect domestic enterprise
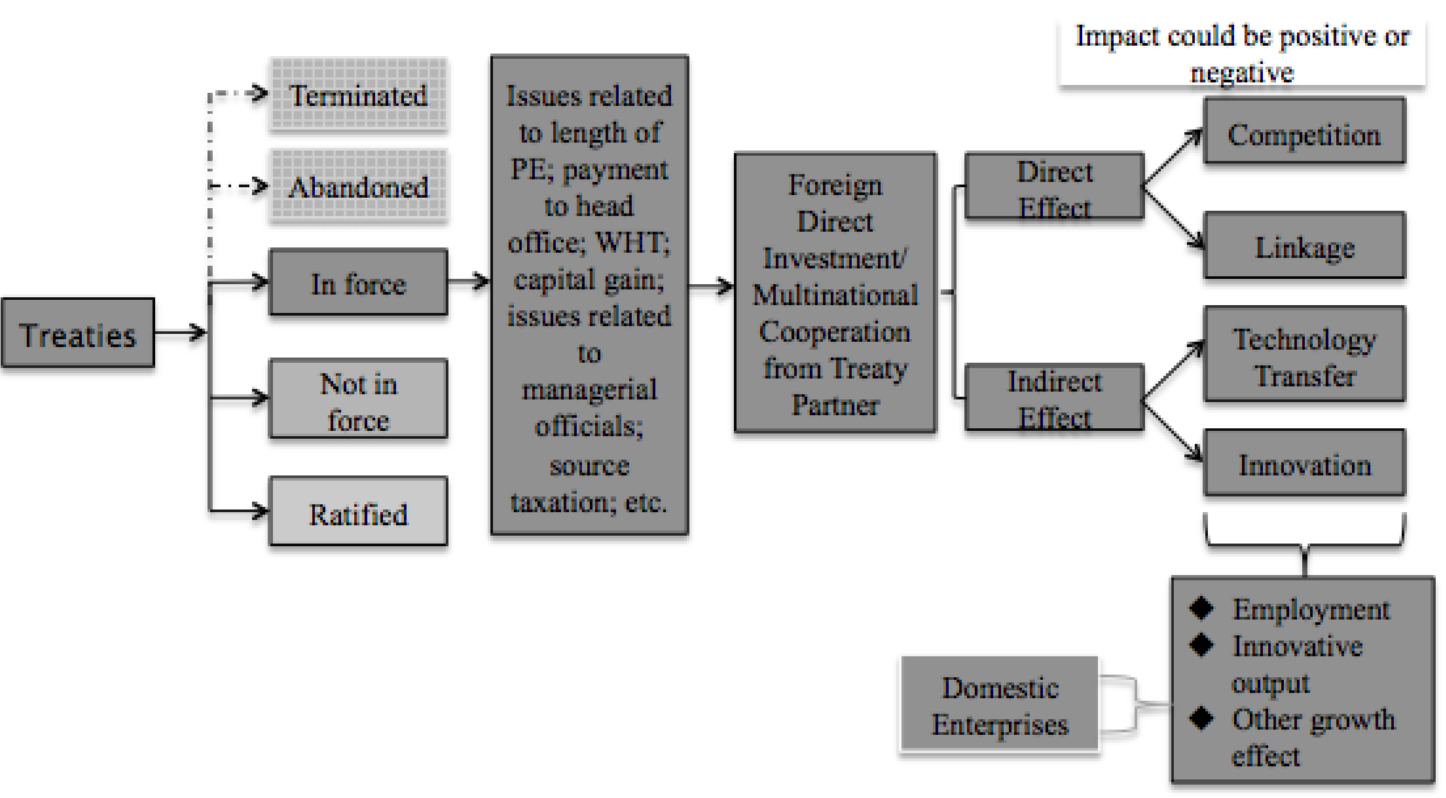